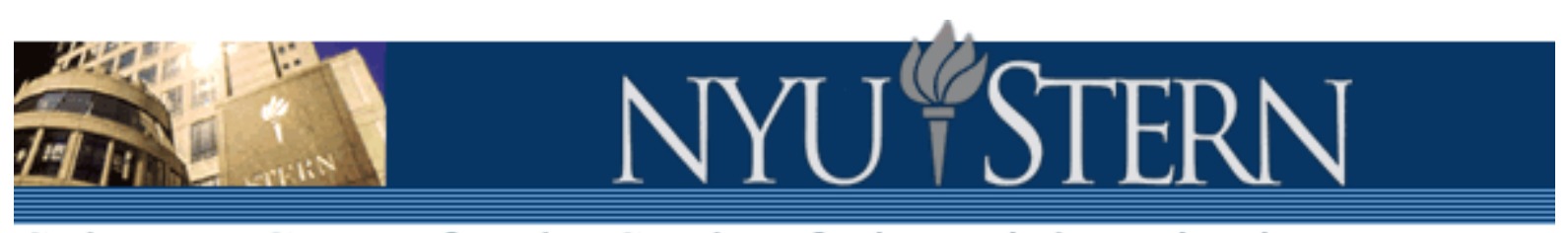

Salomon Center for the Study of Financial Institutions

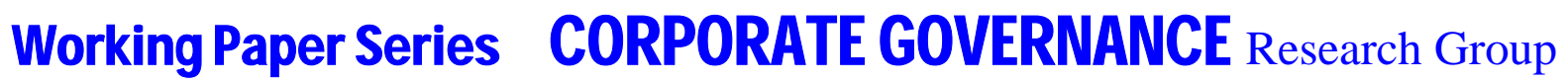

\title{
TENDER OFFERS AND LEVERAGE
}

Holger M. Mueller

Fausto Panunzi

S-CG-03-02 


\title{
Tender Offers and Leverage*
}

\author{
Holger M. Müller ${ }^{\dagger} \quad$ Fausto Panunzi ${ }^{\ddagger}$
}

July 2003

\begin{abstract}
We examine the role of leverage in tender offers for widely held firms. Leverage allows raiders to appropriate part of the value gains arising from takeovers, hence reducing the takeover premium and mitigating the free-rider problem. Leveraged takeovers may thus be profitable even if target shareholders are dispersed. Bankruptcy costs, incentive problems on the part of the raider, and defensive leveraged recapitalizations and asset sales by the target management all limit the raider's ability to borrow, thus shifting takeover gains to target shareholders and reducing the takeover likelihood. While bankruptcy costs are a social cost, the takeover premium is merely a wealth transfer to target shareholders. As the raider does not maximize social welfare, he uses too much debt compared to the social optimum.
\end{abstract}

\footnotetext{
${ }^{*}$ We are particularly indebted to Marcel Kahan for his generous help and advice. Thanks also to Franklin Allen, William Allen, Heitor Almeida, Lucian Bebchuk, Oliver Hart, David Hirshleifer, Laurie Hodrick, Lasse Pedersen, Raghu Rajan, Andrei Shleifer, Jeremy Stein, and seminar participants at Harvard, NYU, and the workshop "New Ideas and Open Issues in Corporate Finance" in Amsterdam (2003) for helpful comments and suggestions. For comments on an earlier version, we thank Arturo Bris, Franz Hubert, and Roman Inderst. This collaboration was initiated during the European Summer Symposium in Financial Markets (ESSFM), 2001. We thank the organizers, CEPR and Studienzentrum Gerzensee, for their hospitality.

${ }^{\dagger}$ New York University \& CEPR. Address: Department of Finance, Stern School of Business, New York University, 44 West 4th Street, Suite 9-190, New York, NY 10012-1126. Email: hmueller@stern.nyu.edu.

${ }^{\ddagger}$ Università di Bologna \& CEPR. Address: Dipartimento di Scienze Economiche, Università di Bologna, Piazza Scaravilli, 2, 40126 Bologna, Italy. Email: fpanunzi@economia.unibo.it.
} 
What this all comes down to is simply withdrawing the warm blood of equity and replacing it with the cold water of debt. Fred Hartley, CEO of Unocal. ${ }^{1}$

\section{Introduction}

The 1980s marked a dramatic change in corporate governance. Pygm-sized financial buyers like Kohlberg, Kravis, Roberts, \& Co and raiders like Carl Icahn, T. Boone Pickens, and Ronald Perelman challenged the leadership of some of the nation's largest companies. Connie Bruck, in her acclaimed book The Predators' Ball (1988, p.14), writes: "[N]o prey was too large and no predator too inconsequential - so long as Milken could tap into his magic pools of capital. Overnight, all the rules of survival in the corporate jungle had been rewritten."

Ownership of target firms was often dispersed. To gain control of the target, the raider would then typically make a tender offer. One of the characteristic features of the 1980s takeover wave is that tender offers were highly leveraged (Scherer (1988), Holmström and Kaplan (2001)). As the raider had typically no, or only few, assets of his own, the assets of the target firm would serve as security for his debt. This is known as bootstrap acquisition, as it enables "the buyer to "bootstrap" the acquisition of a business and pay off the indebtness with money earned in the acquired company's operations" (Crawford (1987, p.1)). The vast majority of LBOs were structured this way.

Compared to its empirical relevance, relatively little is known about the economic role of leverage in tender offers. Beginning with Grossman and Hart (1980), a large literature has analyzed tender offers in which target shareholders are non-pivotal, leading to the well-known holdout (or free-rider) problem (e.g., Shleifer and Vishny (1986), Stulz (1988), Grossman and Hart (1988), Hirshleifer and Titman (1990), Hirshleifer (1995), Burkart, Gromb, and Panunzi (1998)). All these papers assume that the raider finances his bid with cash out of his own pocket. That is, the question of how the raider should optimally finance his bid, and how this might affect the tender offer outcome, is not explored. On the other hand, a number of papers examine the role of the means of payment in takeovers (e.g., Hansen (1987), Fishman (1989)). The focus of these papers is different from ours. ${ }^{2}$ In particular, none of these papers considers

\footnotetext{
${ }^{1}$ When faced with a hostile takeover bid by T. Boone Pickens (Wasserstein (1998, p.146)).

${ }^{2}$ In Hansen (1987) and Fishman (1989) the means of payment (debt, equity, cash) serves as a signalling device. Related is also Chowdhry and Nanda (1993), who examine the effect of bidder leverage on bidding competition.
} 
the holdout problem that is characteristic of widely held firms. Instead, these papers assume that target shareholders sell whenever they make a profit.

This paper studies the role of leverage, and, more generally, the role of financing choice, in tender offers for widely held firms. To isolate the effects of financing choice from previously studied effects, we initially abstract from dilution, freezeouts, and toeholds. Our starting point is the observation that leverage reduces the posttakeover share value, and thus the price at which dispersed target shareholders are willing to tender their shares. This allows the raider to extract part of the value gains arising from the takeover, thus making socially efficient takeovers profitable. One policy implication from this is that restricting the use of leverage in takeoversa common practice in many European countries - might hamper the efficacy of the market for corporate control. In terms of economic effects, leverage works similar to dilution: It reduces the posttakeover share value and hence the incentives of target shareholders to hold out. Unlike the dilution mechanisms proposed by Grossman and Hart (1980), however, the transaction structure underlying LBOs ("bootstrap mechanism") is (i) common and (ii) consistent with both the law and legal practice in the U.S..$^{3,4}$

In a bootstrap acquisition, the raider borrows against the future assets of the combined firm. The debt is issued by a special acquisition vehicle which — after the raider has gained control — is merged into the target firm to provide debtholders with a legal recourse to the pledged assets. Hence there are two steps: a tender offer and a subsequent merger. ${ }^{5}$ What is important is that the debt assumed by the raider enters into the combined firm's capital structure, where it lowers the firm's equity value and thus the takeover premium. ${ }^{6}$ This effect is consistent with

Like Hansen and Fishman, the authors do not consider the free-rider problem.

${ }^{3}$ LBOs were particularly common in the 1980s: In 1986, for instance, LBOs represented nearly 40 percent of all public acquisitions. The use of LBOs finally came to a halt when the junk bond market collapsed: In 1991, the total value of LBO and MBO transactions fell to $\$ 1$ billion from $\$ 80$ billion in 1988 (Jensen (1993)).

${ }^{4}$ Another potential benefit of LBOs is pointed out by Jensen (1986). While his argument that debt limits the ability of managers to squander funds is compelling, the same result can be achieved by financing the takeover with equity and leveraging the company after the takeover. By contrast, it is crucial for our argument that the takeover itself is being leveraged.

5 "The merger step is, of course, essential to permit the buyer to restructure the assets of the target company and use them to repay acquisition debt" (Scharf, Shea, and Beck (1991, p.331)). Courts view the tender offer cum merger as one transaction (Wieboldt Stores, Inc. v. Schottenstein, 94, Bkptcy. Rptr. 488,502 (N.D. Ill. 1988$)$ ).

${ }^{6}$ This aspect of LBOs has hitherto received little attention. An exception is Scherer (1988, p.77ff), who notes that a "promiment characteristic of takeovers in the 1980s is the extensive use of debt financing, introducing increased leverage into the merged company's financial structure" (italics added). 
empirical evidence. Maloney, McCormick, and Mitchell (1993) document a positive relation between bidder returns and the bidder's debt-equity ratio. Similarly, Lang, Stulz, and Walkling (1991) find that target returns are negatively related to the bidder's leverage.

The relation to previous literature is now evident. In the literature, the raider generates a value improvement $v$, which may be best thought of as an improvement in the value of the firm's assets. The question is whether such value-increasing takeovers can materialize given that target shareholders are dispersed. In pevious models, the bid price is financed with cash out of the raider's pocket. Absent any increase in debt, the posttakeover equity value then increases by the same amount as the assets, $v$. To induce target shareholders to tender, the raider must consequently offer a takeover premium of $v$, which implies he makes no profit. With epsilon transaction costs, the takeover fails (Grossman and Hart (1980)). Evidently, the outcome is similar if the raider finances his bid by issuing equity: An increase in the value of the assets by $v$ translates again into an increase in the posttakeover equity value by the same amount.

Suppose now the raider finances his bid by issuing debt $D \leq v$ backed by the combined firm's assets. (On the assumption that $D \leq v$, see below.) Unlike above, the combined firm's equity value only increases by $v-D$. While the raider still brings in a value improvement of $v$, part of this value improvement, $D$, has now already been pledged to a third party (debtholders) ex ante. The net increase in the combined firm's equity value - and thus the takeover premium - is therefore only $v-D$. Given that target shareholders no longer extract the full value improvement $v$, but only a fraction, the takeover may be profitable. The crux is that the proceeds from the debt issue are not added to the firm's assets. They are used to pay for the tendered shares and transaction costs. ${ }^{7}$

The type of transaction structure examined here - including the second-step merger - is both common and legal. ${ }^{8}$ Legal foundations are discussed in the paper. Let us therefore be brief. The right to effect the merger is given by law. Depending on the circumstances, minority shareholders have one of two remedies: They can seek judicial appraisal of their shares, or they can or sue the raider for breach of fiduciary duty. De facto, neither is an issue here since along with his debt, the raider also brings in the value improvement.

Let us provide a simple example. In the example, the proceeds from the debt issue are just

\footnotetext{
${ }^{7}$ By the same logic, if the raider has private wealth, he would optimally not want to bring it into the merged company. This is why in practice the acquisition vehicle carrying the debt is set up as a limited liability company.

${ }^{8}$ For a recent example of a second-step merger in which minority shareholders received shares in the combined firm, see In re Pure Resources, Inc. Shareholders Litigation, C.A. No. 19876 (2002).
} 
sufficient to pay for the tendered shares. In the paper, we show that if this is not the case, the raider can additionally issue equity to cover the remainder. The qualitative results remain the same. Similarly, our qualitative results hold if the proceeds from the debt issue exceed the required funds. Moreover, both in the example and in the paper, the terms of the merger are the same for debt and equity financing. Specifically, it is assumed that in both cases nontendering shareholders retain their proportionate equity ownership. It is thus not the merger per se that causes a difference between debt and equity, but the fact that debt and equity financing have different effects on the postmerger capital structure. Finally, the example involves a cash offer, where the cash can be raised by issuing either equity or debt. In the paper, we show that the same logic extends to exchange offers, where debt and equity are the medium of exchange.

Example. The target is widely held, has outstanding debt $D=0$, assets $A=$ 50 , and thus equity $E=50$. The value improvement is $v=100$. The offer is for cash, and the question is how the raider should raise the cash. If he issues equity, the combined firm's asset/capital structure is $A=150, D=0$, and $E=150$. To induce target shareholders to tender, the raider must then offer $b \geq 150$ (Grossman and Hart (1980)). The situation is thus the same as in the case where the bid is financed with cash out of the raider's pocket: Target shareholders extract the full value improvement. With epsilon transaction costs, the takeover fails.

Suppose now the raider issues debt $D=75$. (This does not to mean that $D=75$ is optimal.) The combined firm's asset/capital structure is $A=150, D=75$, and $E=75$. Instead of the full $v=100$, the posttakeover share value increases only by $v-D=25$. Accordingly, the raider must bid only $b=75$, which implies target shareholders extract only part of the surplus, namely 25. Consider finally the raider's profit. He raises $D=75$ in the debt issue, pays $b=75$ for the tendered shares, and receives shares worth $E=75$ in return. Hence the raider's profit is 75 , which implies the takeover is profitable as long as transaction costs are below $75 .^{9}$

More generally, any tender offer can be viewed as a bargaining problem, where the raider and target shareholders bargain over some value improvement. Let $\alpha$ and $1-\alpha$ denote the raider's and target shareholders' bargaining powers, respectively. In the Grossman-Hart (1980) setting

\footnotetext{
${ }^{9}$ We have assumed that if $b=75$, all shareholders tender. Strictly speaking, any fraction of tendered shares $\beta \in[0.5,1]$ is an equilibrium. Regardless of $\beta$, however, the raider's profit is always 75 : He raises 75 in the debt issue, pays $75 \beta$ for the tendered shares, and receives shares worth $75 \beta$.
} 
with non-pivotal shareholders, the raider's bargaining power is $\alpha=0 .{ }^{10}$ Debt financing reduces the "size of the pie" over which the parties bargain. Instead of the full $v=100$, they bargain over only $100-D=25$. The rest, 75 , has already been pledged to debtholders. The crux is that the raider can fully recoup $D$ ex ante. His profit is therefore $\alpha(v-D)+D=75$, while target shareholders receive $(1-\alpha)(v-D)=25$. The raider's "effective bargaining power" is thus not $\alpha=0$, but $\alpha^{\prime}=\alpha+(1-\alpha) D / v=0.75 .^{11}$

In our model, it is not optimal to set $D>v$, which would push the posttakeover share value below the pretakeover value. With Pareto dominance as selection criterion, any bid below the pretakeover share value fails. But if the raider must offer at least the pretakeover share value, there is no point in pushing the posttakeover share value below it. Typically, in our model the posttakeover share value exceeds the pretakeover value. Reasons are bidding competition, costly bankruptcy, and ex-post incentive problems on the part of the raider.

If bankruptcy is costly, the socially optimal debt level is that where the raider makes just enough profit to carry out the takeover. Any increase in leverage beyond this point is socially wasteful: It reduces the takeover premium - which is merely a wealth transfer to target shareholders - but increases bankruptcy costs. Since the raider does not maximize social welfare, he borrows too much. Our model suggests that in regimes with high bankruptcy costs fewer takeovers succeed. Those that do succeed, however, command a higher takeover premium.

We next consider the interaction between toehold and leverage. A toehold reduces the benefits of leverage, since the takeover premium must be paid on fewer shares. By contrast, the costs of leverage (bankruptcy costs) are unaffected by the toehold. When trading off bankruptcy costs against takeover premium, the raider issues less debt, which implies a higher takeover premium. This is in contrast to Shleifer and Vishny (1986) and Hirshleifer and Titman (1990), who both argue that toeholds lower the takeover premium.

We subsequently consider defensive leveraged recapitalizations and asset sales by the target management. Previous models of defensive capital structure changes all assume that the takeover is financed with cash out of the raider's pocket (e.g., Stulz (1988), Harris and Raviv (1988), Israel (1991), Zwiebel (1996)). Consequently, none of these papers explores the link

\footnotetext{
${ }^{10}$ With finitely many shareholders, there is a positive probability that any single shareholder is pivotal, implying that $\alpha \in(0,1)$ (Bagnoli and Lipman (1988), Holmström and Nalebuff (1992)). Our argument holds as long as $\alpha<1$. Hence it also applies to pivotal-shareholder settings à la Bagnoli-Lipman and Holmström-Nalebuff.

${ }^{11}$ This is related to the strategic use of debt in Perotti and Spier (1993). There, firms borrow against the future surplus from investments in order to avoid having to share this surplus in the subsequent bargaining with unions.
} 
between target capital structure and bidder leverage. In our model, high target leverage impairs the raider's ability to borrow, thereby reducing the takeover likelihood. ${ }^{12}$ Asset sales (e.g., sales of crown jewels) have a similar effect.

We finally examine the effect of leverage on the raider's incentives to create value. If the value improvement depends on the raider's effort, high leverage creates a debt overhang problem, since part of the benefits goes to debtholders. As a consequence, the raider uses less debt ex ante to improve his incentives ex post. This, in turn, raises the takeover premium.

The rest of the paper is organized as follows. Section 2 presents the model and illustrates the main result. Section 3 examines the tradeoff between bankruptcy costs and takeover premium. Section 4 considers the interplay between toehold and leverage. Section 5 shows how leveraged recapitalizations and asset sales impair the raider's ability to borrow. Section 6 examines the effect of leverage on the raider's incentives to create value. Section 7 discusses legal foundations. Section 8 concludes.

\section{The Model}

The setting is similar to Grossman and Hart (1980), Hirshleifer (1995), and others, except that it incorporates the raider's financing choice. We consider a widely held firm (the "target") facing a potential acquirer (the "raider"). The target has no outstanding debt, and the value of the target's assets (and hence the value of its equity) under the incumbent management is normalized to zero. Both assumptions will be relaxed later.

Tender offers are the only admissible form of takeover. ${ }^{13}$ Without loss of generality, we assume that the control majority is 50 percent. All shares carry the same number of votes. If the raider gains control, the target's assets increase in value by $v>0$. For instance, the raider may have a better use for the assets. The value improvement $v$ is randomly distributed over $[0, \bar{v}]$ with density $f(v)$ and cumulative density $F(v)$.

The medium of exchange is cash. We consider three possible sources of financing: (i) the raider provides the cash out of his own pocket (the case considered in the literature), (ii) he issues equity, and (iii) and he issues debt. We also allow combinations of (i)-(iii). We show that

\footnotetext{
${ }^{12}$ This argument has long been part of the folklore on Wall Street. See Hertzberg, D., Borrowing time: Takeover targets find loading up on debt can fend off raiders, Wall Street Journal, September 10, 1985.

${ }^{13}$ Bebchuck and Hart (2001) show that a combination of tender offer and proxy contest may implement efficient outcomes. In their model, target shareholders have a positive probability of being pivotal.
} 
the optimal financing mix takes a simple form: The raider first solves for the optimal amount of debt. If (and only if) the funds from the debt issue are insufficient to cover his needs, he finances the residual with equity or cash out of his own pocket. Hence there is no need to introduce a separate notation for equity. We assume that the raider issues zero-coupon debt with nominal value $D$ backed by the combined firm's assets. ${ }^{14}$ Hence $D$ is the amount of debt that appears on the combined firm's balance sheet. Capital markets are perfectly competitive.

The sequence of events is as follows. At $t=0$ the raider chooses $D$ and submits a bid $b$ at which he is willing to buy all shares subject to his holding a final stake greater than or equal to 50 percent. That is, the raider makes a take-it-or-leave-it, conditional, unrestricted cash offer. The source of financing is public information, which implies target shareholders rationally anticipate the combined firm's capital structure. ${ }^{15}$

At $t=1$ the target shareholders noncooperatively decide whether to tender their shares. We follow Grossman and Hart (1980) and others in assuming that target shareholders are homogeneous and non-atomic, which implies that no shareholder perceives himself as pivotal. The fraction of tendered shares is $\beta$. The Pareto-dominance criterion is used to select among multiple equilibrium outcomes. ${ }^{16}$

At $t=2$, if $\beta<1 / 2$ the takeover fails. If $\beta \geq 1 / 2$ the takeover succeeds, tendering shareholders receive a total of $\beta b$, and the raider incurs administrative costs $c<E[v]$. As explained in the Introduction, the raider and target subsequently merge. Nontendering shareholders retain their original equity share, i.e., they end up with a fraction $1-\beta$ of the combined firm's equity.

\footnotetext{
${ }^{14}$ In practice, debtholders commit to buying the raider's debt conditional on the tender offer being successful. If the tender offer is not successful, no debt is issued (Bruck (1988, p.106-107), Wasserstein (1998, p.596-597).)

${ }^{15}$ The Offer to Purchase, which is mailed directly to target shareholders, incorporates all essential information contained in the Schedule 14D-1, which is the principal tender offer regulatory document required by Section 14(d) of the Williams Act. This information includes “... 3. The source and amounts of the funds being used for the offer. 4. The purpose of the offer, including any plans to acquire control, liquidate, sell the assets or merge the target, or to make other major changes in the business or corporate structure of the target" (Wasserstein (1998, p.638-639)).

${ }^{16}$ This is a standard way of ruling out "unreasonable" Nash equilibria (Grossman and Hart (1980, p.47)). For instance, no matter how high the raider's bid is, there is always a Nash equilibrium where nobody tenders: If nobody else tenders, shareholder $i$ is indifferent between tendering and not tendering, since the takeover fails no matter what. Likewise, Pareto dominance eliminates Nash equilibria in which the raider acquires the target at a price below its pretakeover value. The superiority of debt financing is not driven by Pareto dominance. If anything, Pareto dominance reduces the effectiveness of debt financing in our model as it imposes a lower bound on the admissible posttakeover share value.
} 
Contemporaneous with, and conditional upon, the merger, the raider implements his business plan. ${ }^{17}$ As a consequence, the assets increase in value by $E[v]$.

At $t=3$ the value improvement $v$ is realized. If $v \geq D$ debtholders receive $D$. If $v<D$ debtholders receive $(1-k) v$, where $k \in(0,1)$ indicates that a fraction of the asset value is lost in bankruptcy. The qualitative results are the same with fixed bankruptcy costs.

As is well known, dilution of minority shares affects the tender decision of dispersed shareholders. Dilution creates "a divergence between the shareholders' valuation and the raider's valuation of the postraid firm ..." (Grossman and Hart (1980, p.46), italics added). This allows the raider to acquire the target's shares at a price below his own valuation. Other potential sources of profit are freezeouts (Yarrow (1985), Amihud, Kahan, and Sundaram (2003)), and toeholds (Shleifer and Vishny (1986)). To isolate the effects of leverage from other sources of profit, we initially abstract from dilution, freezeouts, and toeholds. Our benchmark is thus the case studied in the literature in which tender offers for widely held firms fail because they are unprofitable: "[T]he conclusion that in the absence of dilution and initial holdings the bidder cannot profit holds very generally, so long as target shareholders do not perceive themselves to be pivotal" (Hirshleifer (1995, p.852)).

Let us illustrate the main point by solving the model for the simple case where $v$ is known. If the tender offer is financed with cash out of the raider's own pocket, the posttakeover (i.e., combined firm's) share value is $v$. Since target shareholders tender only if $b \geq v$, the takeover is unprofitable. The same holds if the raider issues equity: Absent any simultaneous increase in debt, the posttakeover share value is again $v$.

Suppose now the raider issues debt with nominal value $D \leq v$. In the absence of uncertainty, the proceeds from the debt issue are also $D$. We proceed backwards. If $\beta<1 / 2$ the takeover fails. By contrast, if $\beta \geq 1 / 2$ the takeover succeeds, and the raider's profit is $\Pi=D-\beta b-c+\beta(v-D)$ : He receives $D$ from the debt issue, pays $\beta b$ for the tendered shares, incurs administrative expenses of $c$, and holds a fraction $\beta$ of the combined firm's equity. We assume that any cash left over after paying for tendered shares and administrative expenses is consumed by the raider. ${ }^{18}$ While

\footnotetext{
${ }^{17}$ See Section 7 on the legal implications of this timing. In practice, the raider can commit to his future course of action through the Schedule 14D-1. Deviations from announcements made in the Schedule 14D-1 constitute a violation of the law.

${ }^{18}$ In practice, the raider might pay himself an upfront management fee. In the $1980 \mathrm{~s}$, LBO firms paid themselves substantial upfront fees out of the funds raised, while in principle they could have waited and earned a higher $e x-$ post return instead (Kaplan and Stein (1993)). In the RJR Nabisco takeover, for instance, up-front fees amounted to over $\$ 780$ million (Burrough and Helyar (1990)).
} 
convenient, this assumption is not critical. Below, we consider the other case where the raider cannot consume upfront, i.e., where the funds can be used only to pay for tendered shares and expenses. The qualitative results are the same.

Since shareholders tender only if the bid price equals or exceeds the posttakeover share value, the raider must offer $b \geq v-D$. In equilibrium, the raider offers just enough to make target shareholders indifferent. The equilibrium bid price is thus $b^{*}=v-D$, in which case a fraction $\beta^{*} \geq 1 / 2$ of shareholders tenders. ${ }^{19}$ The raider's profit is $\Pi=D-c$, implying that $D^{*}=v$. (Because the raider pays a fair price on tendered shares, his profit is the same for all $\beta \geq 1 / 2$.) Finally, the takeover is financially feasible: The amount raised in the debt issue, $D^{*}=v$, exceeds the total financing needs $\beta^{*} b^{*}+c=c$.

In the above example, the raider appropriates the full surplus, which implies all efficient takeovers take place. In Section 3, we show that this clean-cut result no longer obtains if the value improvement $v$ is stochastic. The raider then trades off a lower takeover premium against higher bankruptcy costs. In equilibrium, the takeover premium is strictly positive. Similarly, in Section 6 we show that if the value improvement depends endogenously on the raider's effort, high leverage creates a debt overhang problem. To improve his incentives ex post, the raider issues less debt ex ante. Again, the takeover premium is strictly positive.

If $v$ is neither stochastic nor endogenous, the takeover premium may still be positive. If bidders engage in Bertrand competition, for instance, the equilibrium bid price is $b^{*}=v-c$, which is also the takeover premium. Hence target shareholders appropriate the full efficiency gain. What this shows is that the takeover premium may depend on many factors, such as, e.g., bidding competition. Whether the takeover succeeds or not depends solely on the financing choice, however. If the bid is financed with equity or cash out of the raider's pocket, the raider cannot recoup his transaction cost. Regardless of whether there is bidding competition or not, the takeover then fails. By contrast, if the bid is financed with debt, efficient takeovers are possible. While bidding competition raises the takeover premium, bidders only compete to the point where profits are zero. Hence under bidding competition cum debt financing bidders make no profit, but at least they can recoup their transaction costs.

\footnotetext{
${ }^{19}$ Any $\beta^{*} \geq 1 / 2$ is an equilibrium outcome. Note that there cannot be an equilibrium in which the raider offers $b=v-D$ but only a fraction $\beta<1 / 2$ of shareholders tender. If this were true, the raider would want to raise his bid to $b=v-D+\varepsilon$ in order to resolve the shareholders' indifference. In fact, he would want to choose the smallest $\varepsilon>0$ possible. Since such an $\varepsilon$ does not exist, the unique equilibrium outcome given that $b=v-D$ is $\beta^{*} \geq 1 / 2$.
} 
Finally, if $v$ is deterministic, exogenous, and there is no bidding competition, the takeover premium is still positive if we rule out ex-ante consumption, i.e., if we add a constraint that the raider can use his funds only to pay for tendered shares and administrative expenses. The constraint is $D \leq \beta b+c$. As the unconstrained solution derived above does not satisfy this constraint, the constraint is binding. Inserting the binding constraint in the raider's profit function, we get $\Pi=\beta(v-D)$ : As the raider is not allowed to consume ex ante, he maximizes the value of his posttakeover shareholdings. The unique equilibrium outcome is $D^{*}=(v+c) / 2$ and $b^{*}=(v-c) / 2$, which implies the raider's profit is $\Pi=(v-c) / 2$. The raider and target shareholders thus split the surplus in half. Hence ruling out ex-ante consumption reduces the raider's profit and raises the takeover premium. It does not, however, affect our qualitative result that leveraged takeovers for widely held firms can be profitable.

While the focus here is on cash offers, our qualitative results also extend to exchange offers where target shareholders receive securities of the combined firm instead of cash. To illustrate this, suppose again that $v$ is known. (The argument generalizes to stochastic $v$.) If the medium of exchange is equity, the value of the combined firm's equity is $v$. Hence, target shareholders tender only if they receive shares worth $v$, which implies the takeover is unprofitable. By contrast, if the medium of exchange is debt, shareholders tender if the debt is worth as least as much as the combined firm's equity, whose value is $v-D$. Hence we obtain the constraint $D \geq v-D$. In equilibrium, the raider offers just enough to make shareholders indifferent. The unique equilibrium outcome is therefore $D^{*}=v / 2$, which implies the raider's profit is $\Pi=v / 2-c{ }^{20}$ Hence some, but not all, efficient takeovers take place.

\section{Social versus Private Optimality of Debt Financing}

In this section, we explore the role of costly bankruptcy as a natural counterforce to high leverage. If bankruptcy is costly, the raider trades off a lower takeover premium against higher bankruptcy costs. In equilibrium, the efficiency gain is shared between the raider and target shareholders, which implies the takeover premium is strictly positive. And yet, we show that the raider takes on too much debt compared to the social optimum. That is, social and private optimality of

\footnotetext{
${ }^{20}$ Since $D^{*}=v / 2$, the combined firm's debt and equity have the same value, $v / 2$. Hence target shareholders are indifferent between tendering and not tendering, which implies any $\beta \geq 1 / 2$ is an equilibrium outcome. If a fraction $\beta$ of shareholders tender, the raider's final holdings consist of a fraction $\beta$ of the combined firm's equity and a fraction $1-\beta$ of the debt. Consequently, the raider's profit is $\Pi=\beta\left(v-D^{*}\right)+(1-\beta) D^{*}-c=v / 2-c$.
} 
debt financing do not coincide.

As usual, we proceed backwards. Given some debt level $D$, the posttakeover share value is

$$
\int_{D}^{\bar{v}}(v-D) f(v) d v=\bar{v}-D-\int_{D}^{\bar{v}} F(v) d v
$$

The raider's profit is then

$$
\Pi=(1-k) \int_{0}^{D} v f(v) d v+D \int_{D}^{\bar{v}} f(v) d v-\beta b-c+\beta \int_{D}^{\bar{v}}(v-D) f(v) d v .
$$

The first two terms are the proceeds from his debt issue. Since debt is sold at a fair price, the proceeds equal the expected value of the debt. With probability $\int_{D}^{\bar{v}} f(v) d v$ the firm is solvent, and debtholders receive the full value $D$. On the other hand, with probability $\int_{0}^{D} f(v) d v$ the firm is bankrupt, and debtholders receive $(1-k) v$, which takes into account that a fraction $k$ of the asset value is lost in bankruptcy. The third and fourth terms represent the raider's expenses: He pays $\beta b$ for the tendered shares and $c$ to cover administrative expenses. The last term represents the posttakeover value of raider's equity stake.

As in Section 2, the equilibrium bid price must equal the posttakeover share value

$$
b^{*}=\int_{D}^{\bar{v}}(v-D) f(v) d v
$$

which makes shareholders indifferent between tendering and not tendering. Again, any $\beta^{*} \geq 1 / 2$ is then an equilibrium outcome. The raider's profit is

$$
\Pi=(1-k) \int_{0}^{D} v f(v) d v+D \int_{D}^{\bar{v}} f(v) d v-c=D[1-k F(D)]-(1-k) \int_{0}^{D} F(v) d v-c .
$$

This has an intuitive interpretation: As the raider makes no profit on tendered shares (by (3) tendered shares are sold at a fair price), he maximimzes the expected value of his debt.

Differentiating (4) with respect to $D$, we obtain $d \Pi / d D=1-F(D)-k D f(D)$. Checking the value of the derivative at $D=0$ and $D=\bar{v}$, we have that $1-F(0)-k 0 f(0)=1>0$ and $1-F(\bar{v})-k \bar{v} f(\bar{v})=-k \bar{v} f(\bar{v})<0$. Accordingly, neither $D=0$ nor $D=\bar{v}$ solve the raider's problem, which implies the optimal debt level is characterized by the first-order condition

$$
1-F\left(D^{*}\right)-k D^{*} f\left(D^{*}\right)=0
$$

where $D^{*} \in(0, \bar{v}) .{ }^{21}$ Since $D^{*}<\bar{v}$ we have that $b^{*}>0$. Hence the takeover premium is positive, which implies the efficiency gain is split between the raider and target shareholders.

\footnotetext{
${ }^{21}$ If $k=0$, the first-order condition reduces to $1-F\left(D^{*}\right)=0$, implying that $D^{*}=\bar{v}$, i.e., the raider chooses the maximum possible debt level. Inserting $D^{*}=\bar{v}$ in (4), we obtain $\Pi=\int_{0}^{\bar{v}} v f(v) d v-c$. Hence the raider captures the full efficiency gain, which is the same result as in Section 2 where $v$ was deterministic.
} 
We proceed with a discussion of our results.

(i) The takeover is financially feasible. That is, whenever the raider's profit is positive, he can also raise the necessary funds to pay for the tendered shares and administrative expenses. By (4), if the raider's profit is positive at $D^{*}$, the proceeds from his debt issue are sufficient to cover the transaction costs $c$. The remainder, $D^{*}\left[1-k F\left(D^{*}\right)\right]-(1-k) \int_{0}^{D^{*}} F(v) d v-c$, can be used towards paying for the tendered shares, which $\operatorname{cost} \beta^{*} b^{*}$ altogether. If this is not sufficient, the raider can either issue equity or pay the difference out of his own pocket. If he issues equity, equity investors provide the difference $\beta^{*} b^{*}-\left[D^{*}\left[1-k F\left(D^{*}\right)\right]-(1-k) \int_{0}^{D^{*}} F(v) d v-c\right]$. In return, they receive a share $\alpha$ of the raider's equity stake $\beta^{*}{ }^{22}$ Given that capital markets are perfectly competitive, $\alpha$ is given by

$$
\alpha=\frac{\beta^{*} b^{*}-D^{*}\left[1-k F\left(D^{*}\right)\right]+(1-k) \int_{0}^{D^{*}} F(v) d v+c}{\beta^{*} b^{*}} .
$$

The above argument holds generally: Whenever the raider's profit is nonnegative, the takeover is also financially feasible. If the raider needs additional funds, he either issues equity at a fair price or provides the funds out of his own pocket. As financial feasibility can always be ensured, we ignore this issue in the remainder of the paper.

(ii) The takeover takes place if and only if the efficiency gain $\int_{0}^{\bar{v}} v f(v) d v-c$ is sufficiently large. ${ }^{23}$ We can rewrite the raider's profit (4) as

$$
\Pi=\underbrace{\int_{0}^{\bar{v}} v f(v) d v-c}_{\text {Efficiency Gain }}-\underbrace{\int_{D^{*}}^{\bar{v}}\left(v-D^{*}\right) f(v) d v}_{\text {Takeover Premium }}-\underbrace{k \int_{0}^{D^{*}} v f(v) d v}_{\text {Bankruptcy Costs }} .
$$

At the optimal debt level $D^{*}$, the takeover premium and bankruptcy costs are both positive. If the efficiency gain is too small, the raider's profit is thus negative. Holding $\int_{0}^{\bar{v}} v f(v) d v$ constant and varying $c$, we have that (a) if $c \rightarrow \int_{0}^{\bar{v}} v f(v) d v$ the takeover always fails, (b) if $c \rightarrow 0$ the takeover takes place regardless of $k$, and especially, (c) there exists a unique value

$$
\bar{c}:=\int_{0}^{\bar{v}} v f(v) d v-\int_{D^{*}}^{\bar{v}}\left(v-D^{*}\right) f(v) d v-k \int_{0}^{D^{*}} v f(v) d v
$$

such that the takeover takes place if and only if $c \leq \bar{c}$.

(iii) The amount of debt taken on by the raider exceeds the socially optimal level. While bankruptcy costs are a social cost, the takeover premium is merely a wealth transfer between

\footnotetext{
${ }^{22}$ Equity investors may be thought of as limited partners in the raider's LBO firm. In this case, the LBO firm acquires a fraction $\beta^{*}$ of the target's shares, of which the raider owns $(1-\alpha) \beta^{*}$ and the limited partners own $\alpha \beta^{*}$.

${ }^{23}$ The efficiency gain is an exogenous variable representing the possible value improvement under the takeover. It does not include expected bankruptcy costs, which depend on the raider's optimal debt level $D^{*}$.
} 
the raider and target shareholders. The socially optimal debt level $D_{s}$ is therefore the smallest debt level at which the takeover takes place. Formally, $D_{s}$ is given by ${ }^{24}$

$$
\Pi=(1-k) \int_{0}^{D_{s}} v f(v) d v+D_{s} \int_{D_{s}}^{\bar{v}} f(v) d v-c=0 .
$$

By, (6) the raider minimizes the sum of takeover premium and bankruptcy costs. That is, the raider takes on additional debt as long as the reduction in takeover premium outweighs the increase in bankruptcy cost. Unless by coincidence $\Pi_{D=D^{*}}=0$-in which case private and social optimality coincide - the raider thus takes on too much debt compared to the social optimum.

We summarize our results in two propositions. The first characterizes the (privately optimal) equilibrium outcome.

Proposition 1. In equilibrium, the raider trades off higher bankruptcy costs against a lower takeover premium. The efficiency gain is split between the raider and target shareholders, which implies that some, but not all, efficient takeovers take place. Precisely, the takeover takes place if and only if the efficiency gain is sufficiently large.

The second proposition characterizes the tension between social and private optimality.

Proposition 2. As the takeover premium is a pure wealth transfer between the raider and target shareholders, the raider takes on too much debt compared to the social optimum.

We finally examine the comparative statics of bankruptcy costs. Differentiating (3) and (5) with respect to $k$, we have

$$
\frac{d b^{*}}{d k}=-\frac{d D^{*}}{d k}\left[1-F\left(D^{*}\right)\right]=\frac{D^{*}\left[1-F\left(D^{*}\right)\right]}{f\left(D^{*}\right)+k\left[f^{\prime}\left(D^{*}\right) D^{*}+f\left(D^{*}\right)\right]}>0,
$$

where $f\left(D^{*}\right)+k\left[f^{\prime}\left(D^{*}\right) D^{*}+f\left(D^{*}\right)\right]>0$ is the second order condition for a maximum in (5). Provided the takeover takes place, target shareholders are thus better off in regimes with high bankruptcy costs. If bankruptcy costs are high, the raider chooses less debt, which results in a higher takeover premium. On the other hand, by (6) the raider's profit is decreasing in $k$. Hence if bankruptcy costs are too high, the takeover might not take place.

Proposition 3. An increase in bankruptcy costs reduces the raider's profit and thus the likelihood that the takeover takes place. Given that the takeover takes place, however, an increase in bankruptcy costs raises the takeover premium and therefore benefits target shareholders.

\footnotetext{
${ }^{24}$ Since $\Pi_{D=0}<0$ and $\Pi_{D=D^{*}} \geq 0$, existence of $D_{s}$ follows from continuity.
} 
Whether target shareholders ultimately benefit from bankruptcy costs depends on $c$, and thus on the size of the efficiency gain. As the raider's profit is decreasing in $k$, there exists a critical threshold $\bar{k}(c)$ such that the takeover takes place if and only if $k \leq \bar{k}(c)$. By Proposition 3 , if $k<\bar{k}(c)$ target shareholders unambiguously benefit from an increase in $k$. By contrast, if $k>\bar{k}(c)$ the takeover fails, and target shareholders are better off if $k$ drops below $\bar{k}(c)$.

The critical threshold $\bar{k}(c)$ is the value of $k$ satisfying

$$
\Pi=(1-k) \int_{0}^{D^{*}(k)} v f(v) d v+D^{*}(k) \int_{D^{*}(k)}^{\bar{v}} f(v) d v-c=0,
$$

where $D^{*}(k)$ is given by (5). If $c \leq D^{*}(1) \int_{D^{*}(1)}^{\bar{v}} f(v) d v$ the raider's profit is positive at $k=1$ (and hence at $k<1$ ), implying that $\bar{k}(c)=1$. Conversely, if $c>D^{*}(1) \int_{D^{*}(1)}^{\bar{v}} f(v) d v$ the critical threshold is $\bar{k}(c)<1$. Setting $k=\bar{k}(c)$ and differentiating (9) with respect to $c$ yields

$$
\frac{d \bar{k}}{d c}=\frac{1}{\frac{d D^{*}}{d \bar{k}}\left[1-F\left(D^{*}\right)-\bar{k} D^{*} f\left(D^{*}\right)\right]-\int_{0}^{D^{*}(\bar{k})} v f(v) d v}<0,
$$

where the sign follows from (5). To summarize, if $c$ is low-in which case the efficiency gain is large - target shareholders always benefit from an increase in bankruptcy costs. If $c$ is above a certain level, target shareholders benefit from an increase in bankruptcy costs only if bankruptcy costs are below $\bar{k}<1$, where $\bar{k}$ is a decreasing function of $c$.

\section{Toeholds, Leverage, and Equilibrium Bid Price}

In the previous section, leverage is the only possible source of profit. Abstracting from other sources of profit allowed us to study the effects of leverage in isolation.

In this section, we examine the interplay between two sources of profit: leverage and toeholds. Shleifer and Vishny (1986) argue that a toehold may increase the raider's profit, as he does not face a holdout problem on shares which he already owns at the tender offer. We follow Shleifer and Vishny and Hirshleifer and Titman (1990) by taking the raider's toehold as given. That is, we do not model the optimal toehold acquisition strategy. ${ }^{25}$

The setup is the same as in Section 3. The only difference is that the raider now owns an initial toehold $\omega<1 / 2$ in the target firm. To minimize the use of new notation, we denote the total fraction of shares owned by the raider by $\beta$, which includes the fraction $\omega \leq \beta$ already owned prior to the tender offer.

\footnotetext{
${ }^{25}$ On this, see Ravid and Spiegel (1999) and the literature cited therein.
} 
The posttakeover share value is again given by (1). The raider's profit is

$$
\Pi=(1-k) \int_{0}^{D} v f(v) d v+D \int_{D}^{\bar{v}} f(v) d v-(\beta-\omega) b-c+\beta \int_{D}^{\bar{v}}(v-D) f(v) d v .
$$

In the tender offer, the raider now only acquires a fraction $\beta-\omega$ of the target's shares. By the same argument as before, the raider bids exactly the posttakeover share value, which makes shareholders indifferent between tendering and not tendering. The raider's profit is then

$$
\Pi=(1-k) \int_{0}^{D} v f(v) d v+D \int_{D}^{\bar{v}} f(v) d v-c+\omega \int_{D}^{\bar{v}}(v-D) f(v) d v .
$$

The raider makes again no profit on tendered shares due to the holdout problem. What is different compared to the previous section is that the raider now maximizes the expected value of his debt plus the value of his toehold.

Differentiating (10) with respect to $D$, we obtain $d \Pi / d D=(1-\omega)[1-F(D)]-k D f(D)$, where $d \Pi /\left.d D\right|_{D=0}=1-\omega>0$ and $d \Pi /\left.d D\right|_{D=\bar{v}}=-k \bar{v} f(\bar{v})<0$. Hence neither $D=0$ nor $D=\bar{v}$ solve the raider's problem, which implies the optimal debt level is given by

$$
(1-\omega)\left[1-F\left(D^{*}\right)\right]-k D^{*} f\left(D^{*}\right)=0,
$$

where $D^{*} \in(0, \bar{v})$.

Differentiating (11) with respect to the toehold, we obtain

$$
\frac{d D^{*}}{d \omega}=\frac{1-F\left(D^{*}\right)}{-f\left(D^{*}\right)(1-\omega)-k\left[f\left(D^{*}\right)+D^{*} f^{\prime}\left(D^{*}\right)\right]}<0,
$$

where $-f\left(D^{*}\right)(1-\omega)-k\left[f\left(D^{*}\right)+D^{*} f^{\prime}\left(D^{*}\right)\right]<0$ is the second-order condition for a maximum in (11). Hence the equilibrium debt level is decreasing in the toehold. The intuition is straightforward. The presence of a toehold reduces the benefits of leverage, since the raider only profits from the value reduction of the fraction $1-\omega$ of shares he does not already own. To illustrate this, let us rewrite (10) as

$$
\Pi=\underbrace{\int_{0}^{\bar{v}} v f(v) d v-c}_{\text {Efficiency Gain }}-(1-\omega) \underbrace{\int_{D^{*}}^{\bar{v}}\left(v-D^{*}\right) f(v) d v}_{\text {Takeover Premium }}-\underbrace{k \int_{0}^{D^{*}} v f(v) d v}_{\text {Bankruptcy Costs }} .
$$

As can be easily seen from (13), a reduction in the takeover premium by one dollar increases the raider's profit by only $1-\omega$ dollars. The cost of leverage, on the other hand, remains the same as the toehold has no effect on bankruptcy costs. Consequently, less debt is raised compared to Section $3 .{ }^{26}$ Put differently, leverage not only reduces the posttakeover value of minority shares,

\footnotetext{
${ }^{26}$ This follows from comparing the raider's profit function with and without toehold, (10) and (4), respectively. The only difference between the two is that (10) has an additional term $\omega \int_{D}^{\bar{v}}(v-D) f(v) d v$ representing the posttakeover value of the raider's toehold, which is decreasing in $D$.
} 
but also the posttakeover value of the raider's own toehold. This constitutes an additional cost of leverage that was absent in the previous analysis. Consequently, the raider issues less debt. Since by (3) the equilibrium bid price is decreasing in the raider's debt, the presence of a toehold implies a higher bid price, and thus a higher takeover premium.

Proposition 4. An increase in the raider's toehold reduces the amount of debt taken on by the raider and increases the equilibrium bid price, and therefore the takeover premium.

Proposition 4 stands in contrast to Shleifer and Vishny (1986) and Hirshleifer and Titman (1990), who both suggest that the takeover premium is decreasing in the raider's toehold. In Burkart, Gromb, and Panunzi (1998), on the other hand, the bid price is independent of the toehold. Finally, in Burkart's (1995) overbidding model, the equilibrium bid price is increasing in the toehold, like in our model.

The empirical evidence is mixed. Franks and Harris (1989) find that takeover premia for bids with toeholds below 30 percent are higher than premia for bids without a toehold, but lower than for bids with toeholds above 30 percent. Walking and Edmister (1985), on the other hand, find a negative relation between toeholds and takeover premium. Either result must be viewed with caution. As Franks and Harris (p.243) point out, "part of the gain to targets occurs at the initiation of the toehold, which may be well before our month zero." Consistent with this, Schwert (1996) finds that pre-bid runups constitute on average fifty percent of the premium paid in successful takeovers. We are not aware of empirical work testing the relation between toeholds and the total (i.e., runup plus markup) takeover premium.

A toehold has two effects on the raider's profit. One the one hand, it raises the takeover premium (Proposition 4). On the other, there are fewer shares on which the takeover premium must be paid. In what follows, we analyze the overall effect of a toehold on the raider's profit, and hence on the likelihood that the takeover takes place. By the envelope theorem,

$$
\left.\frac{d \Pi}{d \omega}\right|_{D=D^{*}}=\int_{D}^{\bar{v}}(v-D) f(v) d v>0 .
$$

A change in leverage induced by a small change in the toehold has a zero effect on the raider's profit. The only first-order effect is thus the direct, positive effect that the takeover premium must be paid on fewer shares. ${ }^{27}$

\footnotetext{
${ }^{27}$ We have implicitly assumed that the raider can acquire the toehold at the pretakeover share price. The result holds as long as the acquisition price is below the posttakeover share value. For a model in which noise trading limits the price impact of pretakeover share acquisitions, see Kyle and Vila (1991).
} 
Proposition 5. A higher toehold increases the raider's profit, and thus the likelihood that the takeover takes place.

Proposition 5 is consistent with empirical evidence by Walkling (1985) and Choi (1991). Both find a positive relation between the acquirer's toehold and the likelihood of a takeover.

\section{$5 \quad$ Target versus Bidder Leverage}

To examine the effect of the target's net worth on the raider's borrowing capacity, we now relax the assumption that the target has no assets or debt. As the target management can manipulate the net worth (e.g., by selling assets or undertaking a leveraged recapitalization), the analysis also sheds light on the target's ability to ward off hostile takeovers.

Denote the target's assets in place by $V$. To provide a general framework in which not only the raider's acquisition debt, but also the target's existing debt is risky, we assume that $V$ is distributed on $[0, \bar{V}]$, where $\bar{V}$ can be either finite or infinite. The density and cumulative density functions are $h(V)$ and $H(V)$, respectively.

The value improvement brought about by the raider is modelled as a first-order stochastic dominance (FOSD) shift in the distribution of the assets. If the takeover succeeds, the new density and cumulative density functions are $g(V)$ and $G(V)$, respectively, where $G(V)$ dominates $H(V)$ in the sense of FOSD. Accordingly, if the takeover succeeds, the expected value of the assets in place increases. The (overall) efficiency gain is

$$
\int_{0}^{\bar{V}} V[g(V)-h(V)] d V-c=\int_{0}^{\bar{V}}[H(V)-G(V)] d V-c .
$$

The target has existing debt $B$, which is senior to any additional debt taken on by the raider. ${ }^{28}$ We can rewrite the efficiency gain as

$$
\underbrace{\int_{0}^{\bar{V}} V[g(V)-h(V)] d V-c}_{\text {Total Efficiency Gain }}=\underbrace{\int_{B}^{\bar{V}}(V-B)[g(V)-h(V)] d V-c}_{\text {Appropriable Part of Efficiency Gain }}
$$

\footnotetext{
${ }^{28}$ This biases our results as much as possible against a successful takeover. If the raider could additionally dilute the target's existing debt, his profit would be even greater. Empirically, it seems that expropriation of target debtholders is a second-order effect. While Asquith and Wizman (1990) and Warga and Welch (1993) find that target bondholders indeed make small losses, these losses can explain only a negligible fraction (three and seven percent, respectively) of the shareholder gains. The reason is that target bondholders are typically protected via covenants (Smith and Warner (1979)). Accordingly, Warga and Welch conclude that "the primary impetus for LBOs in our period was not the exploitation of holders of public debt" (p.979).
} 


$$
\begin{aligned}
& +\underbrace{(1-k) \int_{0}^{B} V[g(V)-h(V)] d V+B \int_{B}^{\bar{V}}[g(V)-h(V)] d V}_{\text {Change in Value of Target's Existing Debt }} \\
& +\underbrace{k \int_{0}^{B} V[g(V)-h(V)] d V .}_{\text {Change in Bankruptcy Costs }}
\end{aligned}
$$

The first row on the right-hand side represents the increase in share value minus transaction costs ("appropriable part of efficiency gain"). This value increase is to be divided between the raider and target shareholders.

We can rewrite the second row as

$$
(1-k) \int_{0}^{B}[H(V)-G(V)] d V+B k[H(B)-G(B)]>0,
$$

where the sign follows from FOSD. Hence even if bankruptcy costs are zero and the raider receives the full appropriable efficiency gain, his profit is still smaller than the overall efficiency gain. This is in contrast to Section 3, where all efficient takeovers materialized when $k$ was zero. The reason is straightforward. If the target has outstanding debt, a favorable shift in the asset distribution makes the target debt safer. But if a fraction of the value gains goes to debtholders, the takeover might not be profitable even if target shareholders receive nothing.

Proposition 6. If the target firm has outstanding debt, a fraction of the efficiency gain goes to target debtholders. Hence even if bankruptcy costs are zero and target shareholders receive nothing, some efficient takeovers will not take place.

In the remainder of this section, we analyze the effect of target leverage on the raider's debt capacity, i.e., his ability to raise debt by pledging assets of the combined firm as collateral. As previously, the raider issues debt with face value $D$.

The posttakeover share value equals the difference between the asset value $V$ and the sum of the initial target debt $B$ and the additional debt $D$ issued by the raider, i.e.,

$$
\int_{B+D}^{\bar{V}}(V-B-D) g(V) d V
$$

Analogous to (2), the raider's expected profit is then

$$
\begin{aligned}
\Pi= & (1-k) \int_{B}^{B+D}(V-B) g(V) d V+D \int_{B+D}^{\bar{V}} g(V) d V \\
& -\beta b-c+\beta \int_{B+D}^{\bar{V}}(V-B-D) g(V) d V
\end{aligned}
$$


Consider next the tender game. Hitherto, the Pareto dominance criterion has ruled out "unreasonable" Nash equilibria in which the takeover fails irrespective of how high the raider's bid is. If the target has existing assets, Pareto dominance-besides ruling out equilibria of the sort above - additionally rules out equilibria where target shareholders sell their firm at a price below the pretakeover share value. Another, complementary argument for why bids below the pretakeover value appear unrealistic is bidding competition. If the target can be acquired for less than its pretakeover value, entry by rival bidders will drive up the price. Whether we assume bidding competition or Pareto dominance, the outcome is the same: Bids below the pretakeover share value fail. ${ }^{29}$

If bids below the pretakeover share value fail, the raider has no incentive to overleverage: Adding more debt does not reduce the takeover premium, but only increases bankruptcy costs. Consequently, the posttakeover value will always (weakly) exceed the pretakeover value.

By our usual argument, the raider bids exactly the posttakeover share value, which makes shareholders indifferent between tendering and not tendering:

$$
b^{*}=\int_{B+D}^{\bar{V}}(V-B-D) g(V) d V
$$

Again, any $\beta^{*} \geq 1 / 2$ constitutes an equilibrium outcome. Inserting (16) in (15), we obtain

$$
\Pi=(1-k) \int_{B}^{B+D}(V-B) g(V) d V+D \int_{B+D}^{\bar{V}} g(V) d V-c .
$$

We can rewrite (17) conveniently as

$$
\begin{aligned}
\Pi= & \underbrace{\int_{B}^{\bar{V}}(V-B)[g(V)-h(V)] d V-c}_{\text {Appropriable Part of Efficiency Gain }}-\underbrace{k \int_{B}^{B+D}(V-B) g(V) d V}_{\text {Bankruptcy Costs }} \\
& -\underbrace{\left[\int_{B+D}^{\bar{V}}(V-B-D) g(V) d V-\int_{B}^{\bar{V}}(V-B) h(V) d V\right]}_{\text {Takeover Premium }} .
\end{aligned}
$$

By inspection, the appropriable part of the efficiency is decreasing in $B$. This is the debt overhang problem in Proposition 6. What is less clear is whether the sum of the three terms in (18)and hence the raider's overall profit - is decreasing in $B$. In the Appendix, we show that this is indeed the case. The intuition is simple: An increase in target leverage limits the raider's ability

\footnotetext{
${ }^{29}$ This biases our results again against successful takeovers, since it limits the extent to which the raider can make a profit.
} 
to pledge target assets as collateral for his debt, and therefore his ability to borrow. This is summarized in the following proposition, whose proof is provided in the Appendix.

Proposition 7. An increase in target leverage limits the raider's ability to pledge target assets as collateral, thereby reducing his profit. As a consequence, fewer takeovers take place.

Proposition 7 is consistent with available empirical evidence. Palepu (1986), Billet (1996), and Safieddine and Titman (1999) all find a significant negative relation between target leverage and takeover likelihood.

This section is related to Israel (1991), Stulz (1988), Harris and Raviv (1988), and Zwiebel (1996). Israel assumes that the efficiency gain is divided between the raider and target shareholders according to a preset rule. Hence there is no free-rider problem. In the models by Stulz and Harris and Raviv, target management issues debt to repurchase equity. The target management does not participate in the buyback, which increases its voting power and fosters entrenchment. In Zwiebel's paper, the target management issues debt to commit not to undertake inefficient investments, thus reducing the scope for efficient takeovers.

All of the above papers assume that the acquisition is financed with cash out of the raider's pocket. Our model, by contrast, suggests that target leverage matters because it reduces the raider's borrowing capacity. This idea has long been part of the folklore on Wall Street: "[T]he assumption of debt reduces the target company's debt capacity. If the hostile bidder planned to use the target's surplus debt capacity to fund the acquisition of control, the recapitalization can be an insurmountable barrier" (Wasserstein (1998, p.729)).

Rather than issuing debt, the target management can also sell off assets to impair the raider's borrowing capacity. ${ }^{30}$ It is easy to see that asset sales have a similar effect as an increase in target leverage. Suppose the remaining target assets after the asset sale have value $\max \{0, V-B\}$ with corresponding density $h(V)$ and $g(V)$ before and after the takeover, respectively. If $B=\bar{V}$ all assets have been sold, while if $B=0$ none have been sold. In other words, the higher is $B$, the more assets have been sold. ${ }^{31}$ Evidently, the model is isomorphic to our previous model where the target management issues debt. In particular, the raider can only improve the value of those assets that have not been sold, implying that the appropriable part of the efficiency gain shrinks to $\int_{B}^{\bar{V}}(V-B)[g(V)-h(V)] d V-c$. The raider's profit is again given by (18), and

\footnotetext{
${ }^{30} \mathrm{~A}$ special, but important class of asset sales are share repurchases. The asset "sold" in this case is cash. For a discussion of share repurchases see, e.g., Bagwell (1991).

${ }^{31} \mathrm{~A}$ richer model of asset sales would allow the target management to sell off arbitrary subets of $[0, \bar{V}[$.
} 
all results remain the same.

Proposition 8. A defensive asset sale limits the raider's ability to pledge target assets as collateral, thereby reducing his profit. As a consequence, fewer takeovers take place.

There exist numerous examples where firms disposed of cash or assets when facing a takeover threat. For instance, Polaroid bought 22 percent of its shares and put them into a new employee stock ownership plan when threatened by a raider. Likewise, the defensive restructurings by oil companies such as Phillips or Unocal in the 1980s involved substantial increases in cash dividends and the repurchase of equity in the range of 25 to 53 percent. Another example is the sale of crown jewels. For example, in the 1982 takeover fight for Marathon Oil, Marathon granted its white knight U.S. Steel the right to buy Marathon's interest in the valuable Yates oil fields at a bargain price of $\$ 2.8$ billion if an acquirer other than U.S. Steel were to hold more than 50 percent of Marathon's stock (Wasserstein (1998)).

\section{Incentive Effects of Leverage}

In Section 3, we argued that bankruptcy costs pose a natural counterforce to high leverage. In this section, we show that incentive problems on the part of the raider have a similar effect. If the value improvement depends on the raider's effort, high leverage creates a debt overhang problem, as part of the benefits from the raider's effort goes to debtholders. This dulls the raider's incentives. To counteract this, the raider issues less debt ex ante.

The model is similar to Section 3, except that the value improvement is now endogenous. Following Burkart, Gromb and Panunzi (1998), we assume that the raider - after having acquired control - exerts noncontractible effort $e \in[0,1]$ to improve the value of the assets. Precisely, we assume that the value improvement is $v$ with probability $e$ and zero with probability $1-e$. To isolate the incentive effects of debt from the effect studied in Section 3, we abstract from bankruptcy costs. For the same reason, we also assume that the raider owns no toehold. To obtain a closed-form solution for the bid price and equilibrium debt level, we assume quadratic effort $\operatorname{costs} c(e)=\xi e^{2} / 2$, where $\xi>v$ ensures that the optimal effort level is characterized by an interior solution.

In a first-best world, effort is verifiable. The first-best effort maximizes $e v-\xi e^{2} / 2$, implying that $e_{F B}=v / \xi$. The expected value improvement is thus $v^{2} / \xi$. Absent any bankruptcy costs, the optimal debt level is $D_{F B}=v$. The raider's profit equals the proceeds from his debt issue minus 
effort and transaction costs, $e_{F B} D_{F B}-\xi e_{F B}^{2} / 2-c=v^{2} / 2 \xi-c$. Hence the raider appropriates the full (first-best) efficiency gain, which implies all efficient takeovers takes place.

To derive the second-best solution, we proceed backwards. We begin with the raider's effort choice. At this stage, the raider already owns a fraction $\beta$ of the firm's equity, and tendering shareholders have already been paid. The raider maximizes $\beta e(v-D)-\xi e / 2$, which implies the optimal second-best effort is given by

$$
e^{*}=\frac{\beta(v-D)}{\xi} .
$$

(We assume that $D<v$. If $D \geq v$, debtholders cannot break even.)

By (19), the raider's effort is increasing in his equity stake $\beta$ and decreasing in $D$. As $\beta$ increases, the raider internalizes more of the value improvement generated by his effort. On the other hand, the higher the debt, the more gains from his effort go to debtholders, since a higher effort makes the debt safer. As the raider does not internalize this externality, there exists a debt overhang problem similar to that in Section 5. The following holds for any $D \geq 0$.

Proposition 9. The raider expends less effort than in a first-best world without incentive problems. The raider's effort is increasing in his equity stake, but decreasing in the amount of debt, since part of the benefits from his effort go to debtholders.

Consider now the shareholders' tender decision. When deciding whether to tender or not, shareholders compare the raider's bid $b$ to the rationally expected posttakeover share value $e^{*}(v-D)$. The raider's effort $e^{*}$, in turn, depends on the fraction of tendered shares $\beta$. If $b<e_{\beta<1 / 2}^{*}(v-D)$ the bid fails. Conversely, if $b>e_{\beta=1}^{*}(v-D)$ the bid succeeds and all shares are tendered. Both of these bids are dominated and can be ruled out. ${ }^{32}$ Finally, for each bid $b$ between $e_{\beta<1 / 2}^{*}(v-D)$ and $e_{\beta=1}^{*}(v-D)$ there exists a unique Pareto-dominant rational expectations equilibrium outcome in which a fraction $\beta$ of the shares is tendered such that the posttakeover share value $e \beta^{*}(v-D)$ equals the raider's bid (Burkart, Gromb, and Panunzi (1998)). Target shareholders are then indifferent between tendering and not tendering. We call this condition free-rider condition:

$$
b=e^{*}(v-D) .
$$

Inserting the first-order condition (19) in the free-rider condition (20), the equilibrium fraction of tendered shares is

$$
\beta^{*}=\frac{\xi b}{(v-D)^{2}} .
$$

\footnotetext{
${ }^{32} b>e_{\beta=1}^{*}(v-D)$ is dominated since the raider bids more than the highest possible posttakeover share value.
} 
The share supply curve $\beta^{*}(b)$ is upward sloping: By the free-rider condition (20), the bid price must equal the posttakeover share value. A higher bid price thus implies a higher posttakeover share value. But a higher posttakeover share value, in turn, implies a higher $\beta^{*}$, since $e^{*}$ is increasing in $\beta^{*}$ by (19). Moreover, the supply of shares is increasing in $D$ : Debt reduces the posttakeover share value $e^{*}(v-D)$, both directly and indirectly by decreasing $e^{*}$. To ensure that the posttakeover share value remains equal to the bid price, a greater fraction of the shares must be tendered.

Proposition 10. In the unique Pareto-dominant rational expectations equilibrium outcome of the tender game, the fraction of tendered shares is strictly increasing both in the bid price and in the raider's debt.

The free-rider condition (20) implies that the raider makes no profit on tendered shares. His profit consists of the proceeds from the debt issue, $e^{*} D$, minus effort and transaction costs. The raider solves

$$
\max _{b, D} \Pi=e^{*} D-\xi \frac{e^{* 2}}{2}-c
$$

subject to (19), (20) and $\beta \leq 1$. Inserting (19) and (20) into the raider's objective function and partially differentiating with respect to $b$ and $D$, we obtain

$$
\frac{\partial \Pi}{\partial b}=\frac{D}{v-D}-\xi \frac{b}{(v-D)^{2}}
$$

and

$$
\frac{\partial \Pi}{\partial D}=\frac{b}{v-D}\left(1+\frac{D}{v-D}-\xi \frac{b}{(v-D)^{2}}\right) .
$$

The solution is now straightforward: The optimal bid price is given by the first-order condition $\partial \Pi / \partial b=0$, implying that $b^{*}=D(v-D) / \xi$. Inserting this in (22), we obtain $\partial \Pi / \partial D=D / \xi>0$. Hence the optimal debt level is determined by the binding constraint $\beta \leq 1$, which transforms to $D \leq v / 2$ by $(21)$ and $b^{*}=D(v-D) / \xi$. Consequently, the solution is $D^{*}=v / 2, b^{*}=v^{2} / 4 \xi, e^{*}=v / 2 \xi$, and $\beta^{*}=1$, i.e., all shares are tendered. ${ }^{33}$ Inserting the solution back into the raider's profit function, we obtain $\Pi^{*}=v^{2} / 8 \xi-c$.

We conclude with a discussion of the optimal solution.

(i) Leverage has both a direct, negative and an indirect, positive effect on the raider's effort. The direct effect is that - holding $\beta$ constant-leverage creates a debt overhang problem. The

\footnotetext{
${ }^{33}$ This is in contrast to Burkart, Gromb, and Panunzi (1998), where only 50 percent of the shares are tendered in equilibrium.
} 
indirect effect is that an increase in leverage increases $\beta$, and thus the raider's incentives. This is relevant only if $\beta \leq 1$ or, equivalently, if $D \leq v / 2$. If $D>v / 2$, only the negative, direct effect is present. ${ }^{34}$ Accordingly, if $D$ is high, leverage unambiguously reduces the raider's effort.

(ii) Compared to the first-best, the raider issues less debt. The first-best level of debt is $D_{F B}=v$, and therefore twice as high as the second-best level $D^{*}=v / 2$ : To counteract the adverse incentive effects of high leverage in (i), the raider reduces his debt to $D^{*}=v / 2$.

(iii) The reduction in leverage to $D^{*}=v / 2$ raises the takeover premium. In the absence of bankruptcy costs, the first-best takeover premium is zero. The second-best takeoever premium, by contrast, is positive and equal to $b^{*}=v^{2} / 4 \xi$.

(iv) The overall efficiency gain is less than under the first-best. The first-best efficiency gain is $v^{2} / 2 \xi-c$, while the second-best efficiency gain is only $b^{*}+\Pi^{*}=3 v^{2} / 8 \xi-c$. This is due to the fact that, compared to the first-best, the raider exerts less effort $\left(e^{*}=v / 2 \xi\right.$ versus $\left.e_{F B}=v / \xi\right)$.

These results are summarized in the following proposition.

Proposition 11. The optimal debt level is determined by a tradeoff: Leverage increases the raider's equilibrium equity stake, and thus his incentives. On the other hand, it creates a debt overhang problem, which dulls the raider's incentives. If the leverage is sufficiently high, only the negative effect is present. To counteract this-and to improve his incentives ex post-the raider uses less debt ex ante. This, in turn, raises the takeover premium.

\section{Legal Foundations}

As argued in the Introduction, the takeover mechanism analyzed here is widely used in LBOs, and is therefore common. We now argue that it is legal. We focus on Delaware law, where more than half of the Fortune 500 companies are incorporated. Laws in other states are similar. Two issues must addressed, both relating to the second-step merger following the tender offer: (i) legality of the merger itself, and (ii) legality of the terms of the merger.

The power to effect the merger is given by the law. A regular (i.e., long-form) merger must be approved by a simple majority. ${ }^{35}$ Hence if the raider controls a majority of the target's shares, approval is guaranteed. If the raider controls 90 percent or more of the target's shares,

\footnotetext{
${ }^{34}$ For the quadratic effort cost function used here, the positive, indirect effect dominates the negative, direct effect for all $\beta \leq 1$ or, equivalently, for all $D \leq v / 2$, which is why $D \leq v / 2$ is also the solution.

${ }^{35}$ Del. Gen. Corp. L. $\S 251$.
} 
he can alternatively effect a short-form merger. ${ }^{36}$

Depending on the type of merger, minority shareholders have appraisal rights or the right to sue the raider for breach of fiduciary duty. In a regular stock-for-stock merger, target shareholders have no appraisal rights when the target is a listed company. ${ }^{37}$ However, under the "entire fairness" standard laid out in Weinberger $v$. UOP, Inc., the raider must establish that the merger was fair, which includes both "fair dealing" and "fair price". ${ }^{38}$ In a short-form merger, minority shareholders have appraisal rights, but - according to case law - no right to sue the raider for breach of fiduciary duty. ${ }^{39}$ In an appraisal proceeding, the court independently determines the "fair value" of the target's shares. Whether the issue is one of appraisal or breach of fiduciary duty, it therefore ultimately boils down to finding a "fair value" for the target's shares (Bebchuk and Kahan (2000)).

What is a "fair value"? According to Delaware law, "the Court shall appraise the shares, determining their fair value exclusive of any element of value arising from the accomplishment or expectation of the merger" (Del. Gen. Corp. L. $\S 262$ (h), italics added). Hence the law grants minority shareholders no right to a share in the merger gains. Consequently, a fair value is any value under which minority shareholders are not worse off than before the merger (Mahoney and Weinstein (1999)). In our model, the raider implements his business plan contemporaneous with, and conditional on, the merger ${ }^{40}$ At the date of the merger, the value of minority shares

\footnotetext{
${ }^{36}$ Del. Gen. Corp. L. $\S 253$. A short-form merger requires no vote: It is "a simple, fast and inexpensive process for accomplishing a merger" (Glassman v. Unocal Exploration Corp., 777 A.2d 242 (Del. 2001)).

${ }^{37}$ Del. Gen. Corp. L. $§ 262(b),(1)-(2)$.

${ }^{38}$ Weinberger v. UOP, Inc., 457 A.2d, 701 (Del. 1983).

${ }^{39}$ Glassman v. Unocal Exploration Corp., 777 A.2d 242 (Del. 2001). This is provided there is no fraud and the
} offer is accompanied by complete disclosure of all material facts.

${ }^{40}$ On the timing of the raider's value improvement, see Section 2. In practice, such timing is indeed important. In Cede v. Technicolor, the court awarded minority shareholders a share in the merger gains, arguing that the raider's business plan was already in effect at the date of the merger, and thus de facto part of the target's going concern (Cede 8 Co. v. Technicolor, Inc., 684 A.2d 289 (Del. 1996)). The received view among legal scholars is that the raider could have avoided this verdict by waiting with the implementation of his plan until the merger is completed (e.g., Mahoney and Weinstein (1999)). In our model, this issue does not arise since the business plan (value improvement) is implemented contemporaneous with the merger. Hence the correct going concern - and thus the benchmark against which the postmerger value must be compared according to Delaware law $(\S 262(\mathrm{~h}))$ - is the pretakeover share value excluding the raider's value improvement. This value is zero in our model-except for Section 5 , where it is $\int_{B}^{\bar{V}}(V-B) h(V) d V>0$. Since the postmerger value never falls below this benchmark - in fact, it is strictly higher-minority shareholders maintain their going concern value, which 
thus increases from zero (pretakeover value) to $(1-\beta) E[v-D]$ (postmerger value). Since in our model $E[v-D]>0$, minority shareholders are never worse off. In fact, they are strictly better off compared to before the merger. ${ }^{41}$

Legal aspects are also important when it comes to the coexistence of different mechanisms that can potentially mitigate the free-rider problem. Consider first dilution. According to Grossman and Hart (1980), the raider may pay himself a large salary out of the company's funds or issue shares to himself, sell the company's assets at below their true value to another company which he owns, or sell the firm's output at an artificially low price, again to a company which he owns. As has been noted elswhere (e.g., Bebchuk (1985), Amihud, Kahan, and Sundaram (2003)), such practices are unlawful as they violate the raider's fiduciary duty vis-à-vis minority shareholders. While the law may not always be enforced perfectly, any argument in which dilution plays a central role must address the notion of imperfect law enforcement explicitly.

In a freezeout, the raider optimally offers the same back-end price as in the tender offer (e.g., Amihud, Kahan, and Sundaram (2003)). ${ }^{42}$ Suppose the optimal back-end price is $P<$ $E[v-D]$. (For simplicity, we have expressed the back-end price in terms of the firm's total equity; minority shareholders receive only their pro rata share $(1-\beta) P$.) While a back-end price below the posttakeover share value does not violate the law, the law provides no guarantee that the freezeout will go through at this price. ${ }^{43}$ Suppose with probability $1-\varepsilon$ the freezeout goes through at $P$. With an arbitrarily small probability $\varepsilon>0$, however, the court awards minority shareholders the full posttakeover share value $E[v-D]$ (precisely: their pro rata share $1-\beta$ ). In this case, it is a dominant strategy for target shareholders not to tender. (In game-theoretic parlor: The equilibrium with back-end price $P<E[v-D]$ is not trembling-hand perfect). To

implies $\S 262(\mathrm{~h})$ is satisfied.

${ }^{41}$ What if the value improvement is common knowledge to the shareholders and the raider, but hard to verify vis-à-vis a court? The raider's debt, on the other hand, is verifiable. In the event of a litigation, the raider might be able to prove that minority shareholders are not worse off by using the postmerger share price as evidence. If the share price correctly reflects all fundamentals, an appraisal will generate the same result. In the model, we abstract from such issues. Along with the rest of the literature, we assume that the value improvement exists and is verifiable ex post.

${ }^{42}$ If the back-end price is lower than the tender offer price, the offer is coercive. Coercive offers are inconsistent with the notion of a "fair price" (In re Pure Resources, Inc. Shareholders Litigation, C.A. 19876 (Del. 2002$)$ ). Moreover, they are often infeasible due to "fair-price" provisions in corporate charters or state takeover laws.

${ }^{43}$ This is reflected in recent case law. See Cede v. Technicolor (op.cit.) and ONTI, Inc. v. Integra Bank, 751 A.2d 904 (Del. Ch. 1999). 
make target shareholders indifferent between tendering and not tendering, the raider must set both the bid price in the tender offer and the back-end price equal to $E[v-D]$. The takeover premium then again depends on the amount of debt taken on by the raider. While this is merely a model sketch, it illustrates how freezeouts and leverage might interact.

\section{Conclusion}

The high use of leverage is one of the characteristic features of the 1980s takeover wave (Scherer (1988), Holmström and Kaplan (2001)). And yet, relatively little is known about what role, if any, leverage plays for the takeover process. In this paper, we show that - by borrowing against value improvements arising from the takeover - the raider can appropriate part of the takeover gains. Effectively, the raider does not just bring in a value improvement (as assumed in the literature), but a value improvement that comes with a pre-existing liability. The crux is that the proceeds from issuing this liability do not go to target shareholders. Instead, they can be used by the raider to finance the takeover. Leveraged takeovers may then be profitable even if there is a free-rider problem à la Grossman-Hart (1980).

The use of leverage does not come without costs. High leverage increases expected bankruptcy costs and mutes the raider's incentives to create value. Moreover, the target's incumbent management can sell firm assets or undergo a leveraged recapitalization to weaken the raider's borrowing capacity. These counterforces to leverage imply that the raider typically cannot appropriate the entire surplus, but only a fraction. The actual division of surplus between the raider an target shareholders depends, among other things, on the institutional environment, such as, e.g., takeover legislation and bankruptcy procedures.

Historically, LBOs have played a much bigger role in the United States than in Europe. This is partly due to the more restrictive European (anti-)takeover legislation. ${ }^{44}$ For instance, the Second European Directive on Company Law (1976) prohibits target companies from using their assets to provide security for the acquirer's debt. ${ }^{45}$ Recent developments suggest a possible volteface: In January 2003, the Italian government passed a new legislative decree allowing bidders to use the target company's assets as security for their debt (Italian Civil Code, Section 2501-bis). Consistent with our story, observers argue that the new law will "help to boost activity" and

\footnotetext{
${ }^{44}$ See Berglöf and Burkart (2003) for an overview.

${ }^{45}$ The wording is: "A company may not advance funds, nor make loans, nor provide security, with a view to the acquisition of its shares by a third party" (Article 23, Second European Directive on Company Law).
} 
"make good buyouts cheaper, easier, and safer." 46

An interesting, and to our knowledge still open, question is why the legal environment for LBOs is so much more restrictive in Europe. One possible explanation relates to differences in labor market rigidity. An active market for LBOs - and takeovers in general - involves the reallocation of capital (including human capital) across firms, and possibly the restructuring of entire industries, as the U.S. experience from the 1980s would suggest (Jensen (1993)). The cost of such reallocation is greater the more rigid the labor market. In countries with rigid labor markets, lawmakers may thus be reluctant to introduce a more active market for corporate control, for fear of the consequences this might have on employment. If this is true, a successful reform of the takeover market will have to go hand in hand with a labor market reform. The political economy link between financial and labor markets has recently been stressed by Pagano and Volpin (2001), who examine the tradeoff between investor protection and employment protection. With respect to takeover legislation, a similar tradeoff might help understand why there are differences between Europe and the United States.

\section{Appendix}

Proof of Proposition 7. The proof proceeds in two steps. We first derive the raider's optimal debt level $D^{*}$. We then show that the raider's profit given the optimal debt level is decreasing in $B$. As argued in the main text, the raider never chooses $D$ such that the posttakeover share value is below the pretakeover share value. As the posttakeover share value, (14), is decreasing in $D$, there exists a unique value $\bar{D}$, such that the posttakeover share value exceeds or equals the pretakeover share value if and only if $D \leq \bar{D}$. If $D=\bar{D}$, post- and pretakeover share value are equal, which implies $\bar{D}$ is given by

$$
\int_{B+\bar{D}}^{\bar{V}}(V-B-\bar{D}) g(V) d V=\int_{B}^{\bar{V}}(V-B) h(V) d V .
$$

By the above argument, we can consider a relaxed problem where the raider maximizes (17) subject to $D \leq \bar{D}$. Differentiating (17) with respect to $D$ gives $1-G(B+D)-k D g(B+D)$. At $D=0$ the derivative is strictly positive, implying that there are two solution candidates: $D^{*}=\bar{D}$ and $D^{*} \in(0, \bar{D})$, where the latter is given by the first-order condition

$$
1-G\left(B+D^{*}\right)-k D^{*} g\left(B+D^{*}\right)=0
$$

\footnotetext{
${ }^{46}$ Solani, A., "Italy: LBOs come of age," European Venture Capital Journal, December 1, 2002.
} 
We can now compute the effect of $B$ on the raider's profit. The total derivative of (17) with respect to $B$ at $D=D^{*}$ is

$$
\left.\frac{d \Pi}{d B}\right|_{D=D^{*}}=\left.\frac{\partial \Pi}{\partial B}\right|_{D=D^{*}}+\left.\frac{\partial \Pi}{\partial D}\right|_{D=D^{*}} \frac{\partial D^{*}}{\partial B},
$$

where

$$
\frac{\partial \Pi}{\partial B}=-k D^{*} g\left(B+D^{*}\right)-\int_{B+D^{*}}^{\bar{V}} g(V) d V<0 .
$$

Consider first the case where $D^{*}=\bar{D}$. For $\bar{D}$ to be a solution, it must be true that

$$
\left.\frac{\partial \Pi}{\partial D}\right|_{D=\bar{D}}=1-G(B+\bar{D})-k \bar{D} g(B+\bar{D}) \geq 0 .
$$

Moreover, differentiating (23) we get

$$
\frac{\partial \bar{D}}{\partial B}=\frac{G(B+\bar{D})-H(B)}{1-G(B+\bar{D})}<0
$$

where the sign follows from FOSD.

Consider next the case where the optimal debt level is given by (24). By the envelope theorem, we have that $d \Pi / d B=\partial \Pi / \partial B<0$. Q.E.D.

\section{References}

Amihud, Y., Kahan, M., and Sundaram, R., 2003, The efficiency and welfare foundations of freezeout laws in takeovers, mimeo, New York University.

Asquith, P., and Wizman, T.A., 1990, Event risk, covenants, and bondholder returns in leveraged buyouts, Journal of Financial Economics 27, 195-213.

Bagnoli, M., and Lipman, B.L., 1988, Successful takeovers without exclusion, Review of Financial Studies 1, 89-110.

Bagwell, L.S., 1991, Share repurchase and takeover deterrence, Rand Journal of Economics 22, $72-88$.

Bebchuk, L.A., and Hart, O.D., 2001, Takeover bids vs. proxy fights in contests for corporate control, NBER Working paper 8633.

Bebchuk, L.A., and Kahan, M., 2000, Adverse selection and gains to controllers in corporate freezeouts, in: Concentrated Corporate Ownership, ed. by R. Morck, Chicago: University of Chicago Press. 
Berglöf, E., and Burkart, M., 2003, European takeover regulation, Economic Policy 36, 173-213.

Billet, M.T., 1996, Targeting capital structure: The relationship between risky debt and the firm's likelihood of being acquired, Journal of Business 69, 173-192.

Burkart, M., 1995, Initial shareholdings and overbidding in takeover contests, Journal of Finance 50, 1491-1515.

Burkart, M., Gromb, D., and Panunzi, F., 1998, Why higher takeover premia protect minority shareholders, Journal of Political Economy 106, 172-204.

Bruck, C., 1988, The predators' ball. New York: Simon and Schuster.

Burrough, B., and Helyar, J., 1990, Barbarians at the gate. New York: Harper \& Row.

Choi, D., 1991, Toehold acquisition, shareholder wealth, and the market for corporate control, Journal of Financial and Quantitative Analysis 26, 391-407.

Chowdhry, B., and Nanda, V., 1993, The strategic role of debt in takeover contests, Journal of Finance 48, 731-745.

Crawford, E.K., 1987, A management guide to leveraged buyouts. New York: John Wiley \& Sons.

Fishman, M.J., 1989, Preemptive bidding and the role of the medium of exchange in acquisitions, Journal of Finance 44, 41-57.

Franks, J.R., and Harris, R.S., 1989, Shareholder wealth effects of corporate takeovers: The U.K. experience 1955-1985, Journal of Financial Economics 23, 225-249.

Grossman, S.J., and Hart, O.D., 1980, Takeover bids, the free-rider problem, and the theory of the corporation, Bell Journal of Economics 11, 42-64.

Grossman, S.J., and Hart, O.D., 1988, One Share-One Vote and the Market for Corporate Control, Journal of Financial Economics 20, 175-202.

Hansen, R.G., 1987, A theory for the choice of the medium of exchange in acquisitions, Journal of Business 60, 75-95.

Harris, M., and Raviv, A., 1988, Corporate control contests and capital structure, Journal of Financial Economics 20, 55-86. 
Hirshleifer, D., 1995, Mergers and acquisitions: Strategic and informational issues, Chapter 26 in: Handbooks in Operations Research and Management Science, Vol. 9: Finance, ed. by R. Jarrow, V. Maksimovic, and W.T. Ziemba, Amsterdam: North-Holland.

Hirshleifer, D., and Titman, S., 1990, Share tendering strategies and the success of hostile takeover bids, Journal of Political Economy 98, 295-324.

Holmström, B.R., and Kaplan, S.N., 2001, Corporate governance and merger activity in the United States: Making sense of the 1980s and 1990s, Journal of Economic Perspectives $15,121-144$.

Holmström, B.R., and Nalebuff, B., 1992, To the raider goes the surplus? A reexamination of the free-rider problem, Journal of Economics and Management Strategy 1, 37-62.

Israel, R., 1991, Capital structure and the market for corporate control: The defensive role of debt financing, Journal of Finance 46, 1391-1409.

Jensen, M.C., 1986, Agency costs of free cash flow, corporate finance, and takeovers, American Economic Review 76, 323-329.

Jensen, M.C., 1993, The modern industrial revolution, exit, and the failure of internal control systems, Journal of Finance 48, 831-880.

Kaplan, S.N., and Stein, J.C., 1993, The evolution of buyout pricing and financial structure in the 1980s, Quarterly Journal of Economics 108, 313-357.

Kyle, A.S., and Vila, J.-L., 1991, Noise trading and takeovers, Rand Journal of Economics 22, 54-71.

Lang, L.H.P., Stulz, R.M., and Walkling, R.A., 1991, A test of the free cash flow hypothesis, Journal of Financial Economics 29, 315-335.

Mahoney, P., and Weinstein, M., 1999, The appraisal remedy and merger premiums, USC Law School Working Paper 99-5.

Maloney, M.T., McCormick, R.E., and Mitchell, M.L., 1993, Managerial decision making and capital structure, Journal of Business 66, 189-217.

Pagano, M., and Volpin, P., 2001, The political economy of corporate governance, CEPR Working Paper 2682. 
Palepu, K.G., 1986, Predicting takeover targets: A methodological and empirical analysis, Journal of Accounting and Economics 8, 3-37.

Perotti, E.C., and Spier, K.E., 1993, Capital structure as a bargaining tool: The role of leverage in contract renegotiation, American Economic Review 83, 1131-1141.

Ravid, S.A., and Spiegel, M., 1999, Toehold strategies, toehold laws and rival bidders, Journal of Banking and Finance 23, 1219-1242.,

Safieddine, A., and Titman, S., 1999, Leverage and corporate performance: Evidence from unsuccessful takeovers, Journal of Finance 54, 547-580.

Scharf, C.A., Shea, E.E., and Beck, G.C., 1991, Acquisitions, mergers, sales, buyouts and takeovers: A handbook with forms. Englewood Cliffs: Prentice Hall.

Scherer, F.M., 1988, Corporate takeovers: The efficiency arguments, Journal of Economic Perspectives 2, 69-82.

Schwert, G.W., 1996, Markup pricing in mergers and acquisitions, Journal of Financial Economics 41, 153-192.

Shleifer, A., and Vishny, R.W., 1986, Large shareholders and corporate control, Journal of Political Economy 94, 461-488.

Smith, C.W., and Warner, J.B., 1979, On financial contracting: An analysis of bond covenants, Journal of Financial Economics 7, 117-161.

Stulz, R.M., 1988, Managerial control of voting rights: Financing policies and the market for corporate control, Journal of Financial Economics 20, 25-54.

Walkling, R.A., 1985, Predicting tender offer success: A logistic analysis, Journal of Financial and Quantitative Analysis 20, 461-478.

Walkling, R.A., and Edmister, R.O., 1985, Determinants of tender offer premiums, Financial Analysts Journal 41, 27-37.

Warga, A., and Welch, I., 1993, Bondholder losses in leveraged buyouts, Review of Financial Studies 6, 959-972.

Wasserstein, B., 1998, Big deal. New York: Warner Books. 
Yarrow, G.K., 1985, Shareholder protection, compulsory acquisition and the efficiency of the takeover process, Journal of Industrial Economics 34, 3-16.

Zwiebel, J., 1996, Dynamic capital structure under managerial entrenchment, American Economic Review 86, 1197-1215. 